\title{
分婏前後の乳牛のリポタンパク質中のコレステロール値と
}

トリグリセリド値のプロファイル

\author{
安田英巳 ${ }^{1} \cdot$ 松崎 勉 $^{2} \cdot$ 荒井延明 ${ }^{3} \cdot$ 飯田涼 $介^{4 *} \cdot$ 纐縝雄三 ${ }^{4}$ \\ ${ }^{1}$ 安田獣医科医院，テ152-0034 東京都目黒区緑が丘 1-5-22 \\ 2 紋別家畜診療センター, $=$ 094-0013 北海道紋別市南が丘町 7-41-11 \\ 3 スペクトラム ラボ ジャパン株式会社， T 152-0034 東京都目黒区緑が丘 1-5-22-201 \\ ${ }^{4}$ 明治大学農学部, 干 214-8571 神奈川県川崎市多摩区東三田 1-1-1

\section{Profiles of Lipoprotein Cholesterol and Triglyceride Concentrations in Periparturient Cows}

\author{
Hidemi YASUDA ${ }^{1}$, Tsutomu MATSUZAKI ${ }^{2}$, Nobuaki ARAI ${ }^{3}$, Ryosuke IIDA* and Yuzo KOKETSU ${ }^{4}$ \\ ${ }^{1}$ Yasuda Veterinary Clinic, Midorigaoka 1-5-22, Meguro-ku, Tokyo, Japan 152-0034 \\ ${ }^{2}$ Monbetsu Veterinary Center, Minamigaoka-chou 7-41-11, Monbetsu, Hokkaido, Japan 094-0013 \\ ${ }^{3}$ Spectrum Lab Japan, Midorigaoka 1-5-22-201, Meguro-ku, Tokyo, Japan 152-0034 \\ ${ }^{4}$ School of Agriculture, Meiji University, Higashi-mita 1-1-1, Tama-ku, Kawasaki, Kanagawa, Japan 214-8571 \\ (Received 14 February, 2013/Accepted 30 October, 2013)
}

\begin{abstract}
Summary
Lipoproteins are macromolecule complexes of protein, phospholipids, cholesterol, cholesterol esters, and triglycerides, and the lipoproteins transport cholesterol and triglycerides throughout the animal body. The objective of the present study was to investigate a profile of cholesterol and triglyceride concentrations in four lipoproteins during the peripartum period in Holstein dairy cows. Sixty nine blood samples for lipoprotein analysis were taken from 41 periparturient cows on 16 dairy farms. The analysis determined cholesterol and triglyceride concentrations in four lipoprotein fractions which included chylomicron (CM), very low density lipoprotein (VLDL), low density lipoprotein (LDL), and high density lipoprotein (HDL). Analysis of covariance compared cholesterol and triglyceride concentrations in four lipoprotein fractions between pre- and post-partum periods in cows. Correlation analysis was performed between cholesterol and triglyceride concentrations in the four lipoproteins. Means $( \pm$ SEM) of total concentrations of cholesterol and triglyceride in pre-partum cows were $83.61( \pm 3.9)$ and $14.1( \pm 0.69)$ and $\mathrm{mg} / \mathrm{dl}$, respectively. After calving, the total concentrations of cholesterol and triglyceride decreased to $70.31( \pm 4.07)$ and $5.53( \pm 0.57) \mathrm{mg} / \mathrm{dl}$, respectively. The highest HDL cholesterol concentration and the highest VLDL triglyceride concentration were found among the four lipoprotein fractions. Cholesterol concentrations in all the four fractions decreased from pre-partum to post-partum periods $(\mathrm{P}<0.05)$, whereas triglyceride concentrations in the two fractions of VLDL and CM decreased $(\mathrm{P}<0.05)$. Especially, VLDL cholesterol and VLDL triglyceride concentrations decreased by $70 \%$ or higher. In both pre-partum periods and post-partum periods, cholesterol concentrations were correlated between VLDL, LDL and HDL $(\mathrm{P}<0.05)$, but no such correlations were found for triglyceride concentrations. In conclusion, cholesterol and triglyceride concentrations in four fractions are differently related with the calving in dairy cows.
\end{abstract}

連絡先 : 飯田涼介*

明治大学農学部 5 号館-501A

T214-8571 川崎市多摩区東三田 1-1-1

Tel \& Fax : 044-934-7826

E-mail : riid@shikon.meiji.ac.jp

Keywords : calving, lipoprotein, peripartum, cholesterol 


\section{序 文}

リポタンパク質は，血流でコレステロールやトリグリセ リドなどの脂質を運ぶ大きな分子である。リポタンパク質 は密度 (比重) の違いすなわちコレステロールやトリグリ セリドなどの含有割合によって分類され，密度の低い順に カイミクロン (Chylomicron : CM), 超低密度リポタンパ ク質 (Very Low Density Lipoprotein : VLDL), 低密度リポ タンパク質 (Low Density Lipoprotein : LDL)，および高密 度リポタンパク質（High Density Lipoprotein : HDL）と呼 ばれている。

消化管由来の脂質は，小腸から $\mathrm{CM}$ としてリンパ管に 分泌され，血中を経て肝蔵に入る。一方，肝蔵で生成され た内因性の脂質は，VLDL となって蓄積または輸送され る ${ }^{5)}$ VVLDL は肝蔵や血管壁に存在するリポタンパクリパー ゼによって分解され LDL となり, 末梢組織に脂肪酸, コ レステロールを与える。HDL は主に肝蔵と小腸で合成さ れ, 循環血液中に流出し, 未梢組織からコレステロールを 集めて肝臓に取り込まれる5)。

乳牛では, 飼料中の脂肪量と, 血中コレステロール值と 血中トリグリセリド值との正の関連が報告されてい

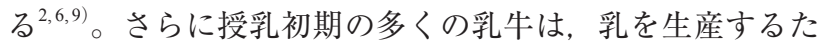
めに負のエネルギーバランスになり ${ }^{8)}$ ，身体からの代謝で 不足エネルギーを補うため, 総コレステロールと総トリグ リ七リドの血中レベルの低下が起ることが知られてい $ろ^{2,3)}$ 。とくに脂肪肝は初期授乳期の主な代謝病であり, リポタンパク質の不適切な生成が関係しているとされてい る3)。

最近では，HDL コレステロールは，牛では卵巣ステロ イド形成の基質であることから，HDL コレステロールと 卵胞でのエストロゲン産生との関係が注目されている1)。 さらにリポタンパク質は主に小腸と肝蔵で生成されるた め, 栄養と繁殖をつなぐ因子としても注目されている ${ }^{1,2)} 。$ しかし, 生産現場における周産期の乳牛のコレステロール 值とトリグリセリド值の報告は少なく, 脂質代謝の動態は, 臨床分野に新しい知見をもたらす可能性がある。そこで本 研究の目的は, 周産期の乳牛のリポタンパク質 4 分画での コレステロール值やトリグリセリド值の変化を調べること とした。

\section{材料と方法}

\section{牛と血液サンプル採取}

北海道紋別市に所在する紋別家畜診療センターにおい て, 2007 年の 1 月から 3 月の間に, 本研究に協力的な 16 農場の中から，分娩前後のホルスタイン種の乳牛を便宜的 に41 頭選んだ。16 農場の農場サイズの平均（幅）は, 92
頭（37-236 頭）であった。4 頭のうち 27 頭は複数回採血 が行われ，69 血液サンプルが採取された。69血液サンプ ルのうち, 38 サンプルが分婏前であり，31 サンプルが分 婏後であった。また，スペクトラム ラボ ジャパン株式会 社（東京都目黒区）が集積した乳牛の生産デー夕（産次, 分婏日）を分析に用いた。

\section{リポタンパク質分析と分婏前後の減少割合}

血液は $1,500 \mathrm{~g}$ で 10 分間遠心分離され，血清を採取した 後, 検査会社スカイライト・バイオテック社（秋田県秋田 市）へ冷蔵送付され，同社で分析が行われた。分析はすで に報告されている方法に基づいたリポタンパク質詳細解析 システムにより行われた ${ }^{7,12)}$ 。この方法を用いて, リポ夕 ンパク質の主要 4 分画 (CM, VLDL, LDL, HDL) にお けるコレステロール值, トリグリセリド值の定量データを 得た。 4 分画のコレステロール值とトリグリセリド值の分 婏前後における変化の大きさを示すために，分婏前から分 婏後の減少割合を算出した。例えば，VLDLにおける分婏 前後のコレステロールの減少割合は，（分婏前のVLDL コ レステロール值の平均值 - 分娩後の VLDL コレステロー ル值の平均值)/分娩前のVLDL コレステロール值の平均值 x 100 によって算出した。

\section{統計分析}

すべての統計分析には SAS (SAS Inst., Inc., Cary, NC, U.S.A.）を用いた。記述統計と頻度分布を，プロシージャ UNIVARIATE とプロシージャFREQを用いて調査した。 農場や産次の効果を考慮し，リポタンパク質分画のコレス テロール值とトリグリセリド值の分娩前後での比較を行う ための統計モデルを，プロシージャ MIXED を用いて構築 した。被説明変数は各分画のコレステロール值とトリグリ セリド值とし，説明変数に分娩の前後と産次を用いた。分 婏の前後と産次との 2 因子の交互作用も調査した。統計モ デルでは，分娩前後に複数回採血されたことを考慮するた めに，ランダム効果として各農場に入れ子にされた牛 ID を用いた ${ }^{4)}$ ○らに, 統計モデルの構造式を以下に示した：

$\mathrm{Y}=$ 切片 $+\beta_{1}$ 分娩前後 $+\beta_{2}$ 産次 + 乳牛 $($ 農場 $)+\mathrm{e}$

$\mathrm{Y}=$ コレステロール值とトリグリセリド值を示す。また, 産次の比較には, 説明変数に分娩の前後を用いた。さらに, 分娩からの日数と各值の単回帰分析のために, プロシー ジャREGを用いた。分娩前後別に, リポタンパク質 4 分 画間のコレステロール值とトリグリセリド值の Pearson の 相関係数を算出するために,プロシージャ FREQ を用いた。

\section{結 果}

採血時の平均産次は $2.47( \pm 0.18 \mathrm{SEM})$ であり，その幅 は 0 から 6 であった。分娩からの平均日数は-5.6（土1.11 SEM）日であり，幅は－35 日から 19 日であった。分娩前 
表 1 分婏前後の乳牛のリポタンパク質各分画中のコレステロール值とトリグリセリド值（土SEM）の比較 ${ }^{1}$

\begin{tabular}{|c|c|c|c|c|c|}
\hline リポタンパク質 & 分婏前 & 分画割合 & 分娩後 & 分画割合 & $\begin{array}{c}\text { 分婏前後の } \\
\text { 減少割合 }\end{array}$ \\
\hline 乳牛の頭数 & 38 & & 31 & & \\
\hline 産次 & $2.08 \pm 0.24$ & & $2.94 \pm 0.26$ & & \\
\hline 単位 & $\mathrm{mg} / \mathrm{dl}$ & $\%$ & $\mathrm{mg} / \mathrm{dl}$ & $\%$ & $\%$ \\
\hline \multicolumn{6}{|l|}{ コレステロール值 } \\
\hline 総コレステロール值 & $83.61 \pm 3.90^{\mathrm{a}}$ & 100.00 & $70.31 \pm 4.07^{\mathrm{b}}$ & 100.00 & 15.91 \\
\hline 高密度リポタンパク質（HDL） & $68.35 \pm 2.41^{\mathrm{a}}$ & 81.75 & $61.19 \pm 3.04^{\mathrm{b}}$ & 87.02 & 10.48 \\
\hline 低密度リポタンパク質（LDL） & $13.06 \pm 1.63^{\mathrm{a}}$ & 15.62 & $8.56 \pm 1.43^{\mathrm{b}}$ & 12.17 & 34.46 \\
\hline 超低密度リポタンパク質（VLDL） & $2.14 \pm 0.15^{\mathrm{a}}$ & 2.56 & $0.54 \pm 0.11^{\mathrm{b}}$ & 7.68 & 74.77 \\
\hline カイミクロン (CM) & $0.06 \pm 0.01^{\mathrm{a}}$ & 0.07 & $0.02 \pm 0.01^{\mathrm{b}}$ & 0.03 & 66.67 \\
\hline \multicolumn{6}{|l|}{ トリグリセリド值 } \\
\hline 総トリグリセリド值 & $14.10 \pm 0.69^{\mathrm{a}}$ & 100.00 & $5.53 \pm 0.57^{\mathrm{b}}$ & 100.00 & 60.78 \\
\hline 高密度リポタンパク質（HDL） & $2.12 \pm 0.22$ & 15.05 & $1.92 \pm 0.16$ & 34.66 & 9.43 \\
\hline 低密度リポタンパク質（LDL） & $1.34 \pm 0.05$ & 9.51 & $1.24 \pm 0.21$ & 22.38 & 7.46 \\
\hline 超低密度リポタンパク質（VLDL） & $10.12 \pm 0.58^{\mathrm{a}}$ & 71.82 & $2.30 \pm 0.47^{\mathrm{b}}$ & 41.52 & 77.27 \\
\hline カイミクロン (CM) & $0.51 \pm 0.12^{\mathrm{a}}$ & 3.62 & $0.08 \pm 0.02^{\mathrm{b}}$ & 1.44 & 84.31 \\
\hline
\end{tabular}

${ }^{\mathrm{a}, \mathrm{b}}$ 列内における平均值の異符号間に有意差あり $(\mathrm{P}<0.05)$ 。

${ }^{1}$ 比較には混合効果モデルを用いた。

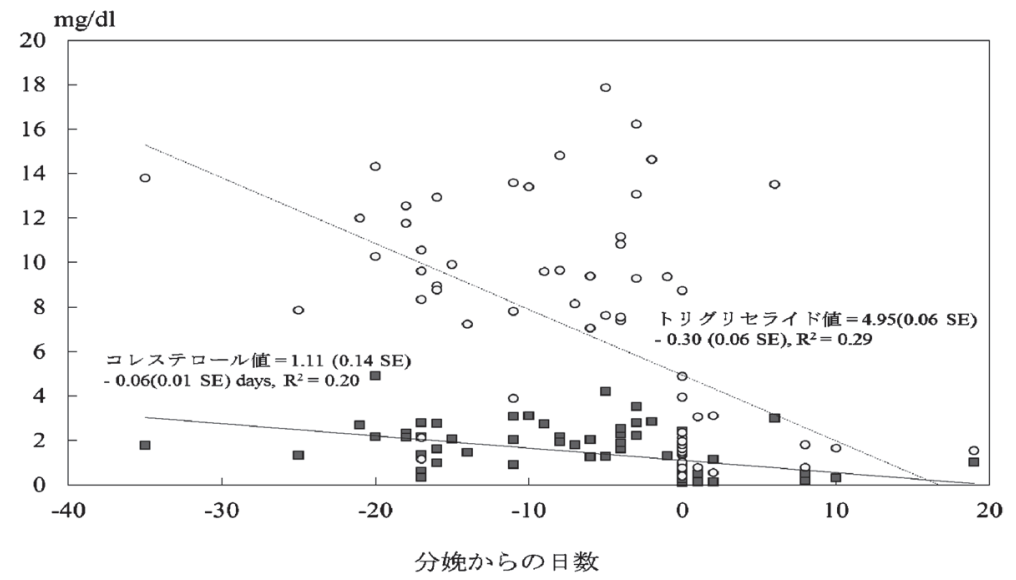

図 1 分娩日からの日数と減少割合が多かった超低密度リポタンパク質（VLDL）のコレステロール值と トリグリセリド值との散布図

後のコレステロール值ならびにトリグリセリド值のそれぞ れの総量，および各分画におけるコレステロール值とトリ グリセリド值と総量に占める割合，さらに分婏前後の減少 割合を表 1 に示した。コレステロール值とトリグリセリド 值は, HDL と LDL 分画のトリグリセリド值を除いて，分 娩の前後で変化があったが $(\mathrm{P}<0.05)$, 産次とは関連がな かった $(\mathrm{P}>0.05)$ 。また, 分娩の前後と産次の交互作用は, コレステロール值およびトリグリセリド值と関連がなかっ た $(\mathrm{P}<0.05)$ 。なお分娩前後での比較では産次に有意差は
なかった $(\mathrm{P}>0.05)$ 。分娩前のリポタンパク質中の総コレ ステロール值と総トリグリセリド值は, それぞれ 83.61 $\mathrm{mg} / \mathrm{dl}$ と $14.10 \mathrm{mg} / \mathrm{dl}$ で, 分娩後は $70.31 \mathrm{mg} / \mathrm{dl}$ と $5.53 \mathrm{mg} / \mathrm{dl}$ に減少した $(\mathrm{P}<0.05)$ 。コレステロール值が最も高かった のは HDL 分画であり, トリグリセリド值が最も高かった 分画はVLDLであった。分娩前で, 総コレステロールの 81.75\% が HDL 分画であり，総トリグリセリドの $71.82 \%$ がVLDL 分画であった。一方, 分娩後では, 総コレステロー ルの $87.02 \%$ が HDL であり，総トリグリセリドの $41.52 \%$ 
表 2 分娩前後の乳牛のリポプロテイン各分画中のコレステロール值 $(\mathrm{mg} / \mathrm{dl})$ の相関関係

\begin{tabular}{llll}
\hline & \multicolumn{3}{c}{ コレステロール值 } \\
& HDL & LDL & VLDL \\
\hline 分婏前 & & & \\
高密度リポタンパク質 (HDL) & 1.00 & - & - \\
低密度リポタンパク質 (LDL) & $0.77 * *$ & 1.00 & - \\
超低密度リポタンパク質 (VLDL) & $0.33^{*}$ & $0.58^{* *}$ & 1.00 \\
カイミクロン (CM) & 0.06 & 0.18 & 0.26 \\
分婏後 & & & \\
高密度リポタンパク質 (HDL) & 1.00 & - & - \\
低密度リポタンパク質 (LDL) & $0.57^{* *}$ & 1.00 & - \\
超低密度リポタンパク質 (VLDL) & $0.32^{*}$ & $0.39 *$ & 1.00 \\
カイミクロン (CM) & $0.43^{*}$ & 0.06 & $0.54 * *$ \\
\hline
\end{tabular}

*は $0.01 \leq \mathrm{P}<0.05$ を示し, **は $\mathrm{P}<0.01$ を示す。

表 3 分娩前後の乳牛のリポプロテイン各分画中のトリグリセリド值 $(\mathrm{mg} / \mathrm{dl})$ の相関関係

\begin{tabular}{lccc}
\hline & \multicolumn{3}{c}{ トリグリセリド值 } \\
& HDL & LDL & VLDL \\
\hline 分婏前 & & & \\
高密度リポタンパク質 (HDL) & 1.00 & - & - \\
低密度リポタンパク質 (LDL) & 0.27 & 1.00 & - \\
超低密度リポタンパク質 (VLDL) & 0.13 & 0.32 & 1.00 \\
カイミクロン (CM) & 0.14 & 0.07 & 0.21 \\
分婏後 & & & \\
高密度リポタンパク質 (HDL) & 1.00 & - & - \\
低密度リポタンパク質 (LDL) & 0.16 & 1.00 & - \\
超低密度リポタンパク質 (VLDL) & 0.02 & 0.16 & 1.00 \\
カイミクロン (CM) & 0.01 & 0.12 & $0.82 * *$ \\
\hline
\end{tabular}

**は $\mathrm{P}<0.01$ を示す。

がVLDL 分画であった。

分娩後には，コレステロール值はすべての分画で減少し

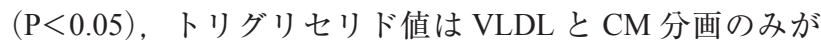
減少した $(\mathrm{P}<0.05)$ 。VLDL と CM 分画のコレステロール 值とトリグリセリド值は, 分娩前後で減少割合が高かった。 分婏前後で減少割合が多かったVLDL 分画のコレステ ロール值とトリグリセリド值，および分娩前後の日の散布 図と, 単回帰分析の結果を図 1 に示した。コレステロール 值とトリグリセリド值は，分娩前後にかけて減少傾向が あった $(\mathrm{P}<0.05)$ 。

表 2 と 3 に, 分娩前・分娩後別に, コレステロール值と トリグリセリド值の各リポタンパク質分画間での相関係数
を示した。コレステロール值では分娩前後とも, HDL と LDL と VLDLの 3 分画間に正の相関があった $(\mathrm{P}<0.05$; 表 2)。また分娩後には，CM と HDL 間と，CM と VLDL 間にも正の相関がみられた $(\mathrm{P}<0.05)$ 。一方，分娩前卜リ グリセリド值は，4 分画間に相関はなかった（表 3$)$ 。そし て，分婏後トリグリセリド值は，VLDL と CM 間でのみ正 の相関があった $(\mathrm{P}<0.05)$ 。

\section{考察}

本研究において, 総コレステロールにおける HDL コレ ステロールの割合が高く，総トリグリセリドにおける VLDL トリグリセリドの割合が高いという結果は, 先行研 
究と一致した ${ }^{1,29}$ 。VLDL の代謝は早い上に2), 多量に存 在することで，分婏前後のトリグリセリドは主にVLDL 分画で運搬されると考えられる。さらに, VLDLによって, 乳腺に運搬されたトリグリセリドは, 乳脂肪生成に使われ ると考えられる ${ }^{10)}$ 。

さらに本研究で VLDL と CM 分画でコレステロールと トリグリセリド值の分婏前後で減少が大きかったことは, この 2 つの分画が, 分婏・泌乳に関係が深いことが考えら れる。このことは, 泌乳期の牛の乳腺は, 外因性 (腸管) 由来の VLDL と CM 分画を介してトリグリセリドを取り 込み, 乳脂肪合成に利用していることを示した過去の研究 に合致するものである ${ }^{11)}$ 。そして HDL と LDL 分画トリグ リセリド值は，分娩前後で大きな変化が見られなかったと いうこと, そしてVLDL分画に比して量も少ないことから, 両分画のトリグリセリドは，分娩や泌乳への関係が薄いこ とを示しているかもしれない。

コレステロール值で, 分婏前後とも, HDL と LDL と VLDL の 3 分画間での相関が見られたことは, コレステ ロールの運搬に, 3 分画のリポタンパク質が強く関係して いることを示した。一方，トリグリセリド值は，分娩後で のみ VLDL と CM 間で強い相関を示した。これは, 分娩 後の泌乳のためのトリグリセリド運搬における両分画間の 強い関係を明らかにした。さらにコレステロール值とトリ グリセリド值で, 分画での変化に差があったこと, 分婏前 後での相関関倸に違いがあったことは，コレステロールと トリグリセリドで，分娩・泌乳への関係が異なることを示 している。

本研究の限界は, リポタンパク質に関し初めての生産現 場での研究ということもあり, 分婏前後の飼料給与法など 栄養管理についての調查や，分婏後初回授精日数や分婏間 隔など繁殖成績のデー夕収集が実施できなかった。さらに 分婏後のケトーシスや乳熱などの症例が少ないため, 疾病 とリポタンパク質の関係が調べられなかった。本研究は, 酪農場で飼育されている分婏前後の乳牛から, 初めてリポ タンパク 4 分画中のコレステロール值とトリグリセリド值 を測定した。今後は，分娩前後の脂質代謝を考慮した飼養 管理や繁殖成績の改善にむけた研究が必要である。

\section{引用文献}

1) Anand, L.N. and Prakash, B.S. : Comparative profiles of different lipoprotein cholesterol parameters and Growth Hormone during hot humid and winter season in Murrah Buffaloes. Livestock Sci., 115, 294-300, 2008.

2) Bauchart, D. : Lipids absorption and transport in ruminants. J. Dairy Sci., 76, 3864-3881, 1993.

3) Bobe, G. et al. : Effects of Exogenous Glucagon on Lipids in Lipoproteins and Liver of Lactating Dairy Cows. J. Dairy Sci., 86, 2895-2903, 2003.

4) Dohoo, I., Martin, W and Stryhn, H. : Veterinary Epidemiologic Research, 2nd edition. VER Inc., Charlottetown, Canada, 2009.

5) Ganong, W.F. : Review of Medical Physiology, $19^{\text {th }}$ ed. 286292, Appleton \& Lange, Stamford, CT, USA., 1999.

6) Grummer, R.R. and Davis, C.L. : Plasma concentrations and lipid composition of lipoproteins in lactating cows fed control and high grain diets. J. Dairy Sci., 67, 2894-2901, 1984.

7) Mizutani, H. et al. : Application of gel permeation HPLC for lipoprotein profiling in dogs. J. Vet. Med. Sci., 72, 813-817, 2010.

8) Overton, T.R. and Waldron, M.R. : Nutritional management of transition dairy cows : Strategies to Optimize Metabolic Health. J. Dairy Sci., 87, Supplement E105-E119, 2004.

9) Park, C.S., Rafalowski, S.W. and Mark, G.D. : Effects of dietary fat supplement on lipid metabolism of Holstein heifers. J. Dairy Sci., 66, 528-534, 1983.

10) Palmquist, D.L. : A kinetic concept of lipid transport in ruminants. A review. J. Dairy Sci., 59, 355-363, 1983.

11) Uchide, T. et al. : Utilization of intestinal triglyceride-rich lipoproteins in mammary gland of cows. J. Vet. Med. Sci., 61, 1143-1146, 1999.

12) Usui, S. et al. : A new online dual enzymatic method for simultaneous quantification of cholesterol and triglycerides in lipoproteins by HPLC. J. Lipid Res., 43, 805-814, 2002. 